\title{
Teacher Perspectives on Teaching the STEM Approach to Educational Coding and Robotics in Primary Education
}

\author{
Christian García-Carrillo ${ }^{1}$, Ileana María Greca ${ }^{2}$ (D) and María Fernández-Hawrylak ${ }^{3, *(D)}$ \\ 1 Unit of Scientific Culture and Innovation, Universidad de Burgos, 09001 Burgos, Spain; \\ christiangarcia1989@gmail.com \\ 2 Department of Specifics Didactics, Universidad de Burgos, 09001 Burgos, Spain; imgreca@ubu.es \\ 3 Department of Educational Sciences, Universidad de Burgos, 09001 Burgos, Spain \\ * Correspondence: mfernandez@ubu.es
}

Citation: García-Carrillo, C.; Greca,

I.M.; Fernández-Hawrylak, M.

Teacher Perspectives on Teaching the STEM Approach to Educational Coding and Robotics in Primary Education. Educ. Sci. 2021, 11, 64 https://doi.org/10.3390/educsci 11020064

Academic Editor: James Albright

Received: 9 January 2021

Accepted: 5 February 2021

Published: 8 February 2021

Publisher's Note: MDPI stays neutral with regard to jurisdictional claims in published maps and institutional affiliations.

Copyright: (c) 2021 by the authors. Licensee MDPI, Basel, Switzerland. This article is an open access article distributed under the terms and conditions of the Creative Commons Attribution (CC BY) license (https:// creativecommons.org/licenses/by/ $4.0 /)$.

\begin{abstract}
An analysis is presented in this study that provides insight into a practical training process and its impact on teachers and their viewpoints toward the integrated STEM approach used in that training process, together with educational coding and robotics, over the first years of compulsory primary education, where STEM implementations are relatively new. A case study was developed by two teachers following the practical training course, including pre- and post-interviews and nonparticipative observation of their classroom practices during the teacher-training sessions. The results revealed the positive perspectives that the teachers held toward the STEM-integrated approach and educational coding and robotics, despite the difficulties that arose in classroom practice. It was concluded that the STEM approach and its methods were beneficial both to pupils and to teachers alike for improving the teaching-learning process.
\end{abstract}

Keywords: science and technology; engineering; mathematics; educational robotics; educational computing; initial teacher training; case study

\section{Introduction}

The fulfillment of the wish to train a scientifically literate public has followed a long path for science to be placed on the educational curriculum at all levels, including early childhood [1-4]. Nevertheless, traditional science teaching has not been of sufficient efficiency for that wish to be fulfilled, and there has been a consensus over several years $[5,6]$ concerning the urgent need for the development of new strategies capable of training people in the languages of science and technology, so that young people may make informed decisions over their career options [7]. Thus, methodologies with constructivist approaches have been proposed [8,9], leaving the traditional methods used in classroom praxis to one side, which have been characterized by knowledge transmission, memorization, and the repetition of scientific content, without considering the preconceptions of pupils and inappropriate practices for learning new skills and knowledge [10-13]. This praxis prevents significative learning and the formation of connections between previous experiences and new knowledge that is rooted in the real world [14], thereby reducing teaching to a set of laws, theories, facts, and concepts [15]. It is a type of teaching that accentuates the protagonism of the teacher and the passive role of the pupil [16,17], which in some instances, appears to lead to pupil failure in scientific subjects and their rejection. Based on these arguments, the abandonment of those teaching designs is proposed in favor of others directed at facilitating scientific activities that motivate teachers and pupils to work together toward the development of new skills [18].

Integrated STEM arises in response to the need for this methodological change, both to incentivize scientific literacy and to increase interest in scientific and technological areas, helping pupils with the resolution of daily problems within their social network [19], and responding to the challenges of scientific and technological education. Many STEM programs 
have been developed in extracurricular hours and for pupils in compulsory secondary education (Educación Secundaria Obligatoria-ESO) [20], with few empirical studies that show how teachers can implement STEM programs within the school curriculum, above all at early stages such as early childhood education (ECE) and primary education (Educación Primaria Obligatoria-EPO). These stages are particularly suited to the structure of schools within which teachers can develop interdisciplinary projects with greater ease, because that is the time when children show greater interest toward scientific topics [21-23].

\section{Theoretical Approach}

Integrated STEM education refers to an integrated approach of the disciplines that form its acronym (science, technology, engineering and mathematics). It has opened an alternative route both for the teaching and the learning of those disciplines [24-27], pursuing the integration and the cohesive development of scientific and technical material within an interdisciplinary framework $[28,29]$. This is done so that central scientific ideas may be explored with experimental components [30], through a more or less extensive integration of the knowledge that arises from the disciplines that form its acronym [29]. Its objective is the development of integrated education from an early age [31].

Integrated STEM education revolves around the resolution of problems within the real environment through investigation and innovation in a way that motivates pupils [28,32-34]. It helps them to become responsible and autonomous participants of their own learning, to develop the necessary competences for progress and co-existence within society, and to improve self-efficacy in the STEM disciplines [35] and the development of their talent [36]. It therefore implies the use of particular didactic methodologies, among which are inquiry-based learning [8,37-39], the methodology of engineering design [23,40,41], and the educational coding and robotics for computational thinking [42-45]. All these methodologies are as follows: student-centered; start and revolve around real problems; promote collaborative learning based on research; include hands-on activities (experiments as well of the design of devices); and help the development of critical thinking, creativity, and autonomous learning. All of them are used as tools to facilitate scientific learning that are capable of significantly improving the competences and skills of pupils by increasing both their interest and their motivation.

The effective application of integrated STEM education with an integrative perspective implies a challenge for teachers [46], because the teacher has to be a guide in the development of scientific skills and competences, which in turn strengthen significative learning, seeking a connection between science and pupils [47]. Erroneous conceptions and procedures of the teachers with respect to science and its nature have nevertheless surfaced in investigations [48], which arise from distorted, ingenuous, and inadequate beliefs [49]. Concerns over teacher training therefore continue to increase, so a long road still stretches out ahead, despite the effort invested to date.

If the idea is to implement this approach in the classroom, teacher training may be proposed as a useful process that can renovate both the practice and the ideas of traditional teaching that theoretical components promote for the successful teaching of science [50,51], moving toward teaching methods more akin to integrated STEM education. Cañal [11] began with the premise that teachers have to orient, design, and reflect upon the teachinglearning process, not only from the perspective of the teacher, but also from the point of view of the pupils, so as to satisfy their curiosity for knowledge.

With regard to the STEM approach, various research projects have coincided over the need for teachers who are involved, with solid knowledge and experience of the disciplines that the approach covers, and who are capable of understanding their methods, in order to introduce them into the classroom [26,52,53]. In STEM-integrated approaches, the teacher must promote innovation through projects and critical thought with the final purpose of the pupils resolving the problems that are proposed $[54,55]$. Nevertheless, a review of the literature [56] shows the difficulties teachers have in doing so, which are fundamentally linked to three aspects: the training received; beliefs and attitudes; and teaching practice. 
With regard to the training to implement STEM approaches, there are shortcomings in both didactic training and the scientific knowledge of teachers that can be lacking on the ground and inappropriate [57]. Some investigations have shown that the negative attitudes of teachers towards educational reform of the sciences are due to their superficial and fragmented conceptual and procedural knowledge [58-60], their lack of sufficient knowledge on scientific content [61], and the scarcity of personal and professional experience and practice of knowing how these contents are best applied in the classroom [18,62]. Thus, teachers may have an inappropriate view of science, technology, and engineering, and of the contents and practices that have to be covered in these areas, thereby constructing incoherent, barely solid, and ineffective concepts for the development of their professional labors. On the other hand, an outstanding characteristic of the training courses and the professional development of teachers imparting scientific content in primary education is that they very often fluctuate between pedagogic and even psychological preparation itself, leaving to one side the treatment of area-specific content, or, on the contrary, they may only be centered on the scientific content, of which almost all is directed toward teachers with a scientific training [63].

With regard to the beliefs and the attitudes of teachers, the negative response to the application of more active teaching and learning methods can be explained by their lack of practice with these methods when teaching the subject matter [64]. Likewise, they considered the methods to be slow and hardly viable [11,65], and, on occasions, a lack of confidence in the methods among pupils meant that they could not work with them [58].

Difficulties with teaching practice arise, in relation to a lack of both resources and knowledge for the development of the inquiry-based method [66], a lack of time due to an excessive extension of the curriculum, added to pressures within institutions and from parents to comply with the full curriculum [67], and the difficulties associated with the organization, economic costs, and dedication of this sort of approach [68].

Various training actions are therefore necessary. In this work, we present the results of one of these actions, the BotSTEM project, funded by the European Commission. The objective of this project is to develop new didactic tools and activities through which integrated STEM proposals for educational coding and robotics may be introduced through innovative methods. Although this training action will be described later, it is basically underlined here as training "in practice".

\section{Materials and Methods}

\subsection{Problems to Investigate and Objectives}

Given the inefficiency of traditional training in sciences, which equates with a drop in interest and lax attitudes among pupils toward science and technology [69-71], it is necessary to renovate the teaching of sciences, starting with teacher training and through strategic and methodological modifications within the classroom, in order to improve attitudes, interest, motivation, and the experiences lived by the pupils [39,72]. Given that the effort of primary teachers is primordial when carrying out STEM-integrated educational practices, a training project is proposed for the first educational stages of formal education with integrated STEM proposals involving educational coding and robotics by employing innovative methodologies.

Taking into account the theoretical justification, the following general objective was proposed that served to guide the investigation:

To understand and to analyze the impact of the training process for teaching through an integrated STEM approach, with educational coding and robotics at the level of primary education.

Three specific objectives were advanced:

- To evaluate the process of conceptual change on teachers with respect to STEM and educational coding and robotics and their teaching methodology. 
- To examine and to analyze the attitudes both of teachers, toward the challenges of their training, and of pupils, from the point of view of the teacher, with regard to those matters.

- To explore the difficulties, the benefits, and both the personal and the professional prejudices of pupils and teachers toward the STEM approach, both in classroom practice and through the perceptions of the teacher.

Two general research questions addressed the objective of the study: (1) What are the conceptual and methodological changes shown by the teachers regarding the STEM approach to programming and educational robotics after completing the teacher training? (2) Which attitudes will the teachers and students adopt after the development of the approach for the learning process and for teaching practice?

\subsection{Design of the Investigation}

A qualitative case-study methodology was chosen for this study [73,74]. A case study is a detailed description that is oriented toward understanding a real event within its natural context; these cases are particular aspects of the participants that give insight into their activity in certain concrete circumstances $[73,75]$. Case studies are intended for the study, analysis, and understanding of a particular reality of the event according to its purposes. The main feature of the case study is the analysis of the complexity of a single case in order to understand its characteristics and functioning under certain circumstances [73]. This type of study was chosen, because it facilitates an understanding of the particular experience of the teachers participating in an educational process and its subsequent praxis within the classroom, helping to interpret the intrinsic meanings of their teaching experience from their own vision [74]. It is an instrumental case study [76], due to the investigators' choice of the topic to study, which converts it into a tool of the problem to be investigated. In this way, it moves beyond being a particular case study and marks out a series of generalizations, in this case, of classroom practice at the primary education stage in relation to the STEM-integrated approach.

\subsection{Phases of the Investigation}

The steps proposed by Stake, and León and Montero [76,77] were followed for the case-study process.

\subsubsection{Selection and Definition of the Case}

The teacher-training model and the methodologies applicable to the Autonomous Region of Castile and Leon and developed from the directives established in Organic Law 8/2013 of December 9 for the improvement of educational quality [78] are fundamentally presented in two documents:

Decree 26/2016 [79] establishes and regulates the implementation, evaluation, and development of primary education in the Community of Castile and Leon. It tells us that the methodologies will be oriented at each stage toward "know-how", creating an integrated process that facilitates the contents for an acceptable practical response around different aspects such as: reflection, criticism, preparation of a hypothesis, and investigative work. To do so, the teachers should assume a creative role in situations for acceptable and motivated learning, in order to achieve the competencies and the capabilities necessary for active participation in real life.

The II Plan for Attention to Diversity in Education of Castile and Leon 2017-2022 [80] includes the different methodologies that are applicable in the classroom. In this case, we take into account those favoring interaction and creation. In the case of those favoring interaction, cooperative learning stands out, as it is a set of teaching procedures based on activities carried out through the organization of pupils into heterogeneous groups within the classroom, where work has to be jointly coordinated, in order to resolve the tasks that the teacher is proposing [81]. Among the methodologies favoring interaction, problembased learning is considered to be a strategy in which importance is given to the knowledge 
that is learned in the process of teaching and learning, such as skills and attitudes. In this type of learning, the pupil is given a real problem on which an investigative process is initiated that leads to a search for solutions to that problem [82].

Teacher training within the BotSTEM project was completed by teachers and researchers involved in the project, through meetings with the participating teachers and continuous support throughout the whole process of implementation within the classroom.

Two initial meetings took place between teachers and the researchers involved in the training. In the first, the project was detailed, the STEM approach procedures were explained, and different materials were facilitated, asking the teachers to revise them and use them. In addition, a forum for questions and doubts and a Moodle course with materials, videos, and documentation was set up online. The second meeting was organized to exchange impressions with the teachers, in order to value the problems related with the didactic materials on offer. At this point of the training, the teachers themselves decided on the topic to be developed in the classroom and outlined a lesson plan. After a feedback process with improvement proposals, the topics were then implemented in the classroom.

Two primary education teachers participated in the research, both of whom were interviewed (a 1st grade EPO teacher and a 2nd grade EPO teacher). They were both employed at a state-assisted school in the city of Burgos (Spain) and had been chosen from among the seven teachers who participated in the project at that educational center. These participants were selected according to their own circumstances and considering their uniqueness. They were voluntary participants and had to meet two previous characteristics stipulated by the researchers: (1) an in-service teacher who had taught in primary education for several years and (2) an in-service teacher following a teacher-training process in relation to the STEM approach to educational programming and robotics. Some weight was also attached to gender parity, years of teaching, and the basic professional training of each teacher: one had followed a scientific training, and the other, a general teacher training.

\subsubsection{Preparation of a List of Questions}

Following the recommendations of Stake [73], the following research questions were formulated in accordance with the proposed objectives:

- Following the teacher-training activities, which conceptual and methodological changes did the teachers implement in relation to STEM and educational coding and robotics?

- What were the attitudes of the teachers and pupils after their experiences of the new approach for the teaching-learning process?

- What difficulties were detected through the use of this new educational approach?

- With regard to the STEM approach to educational coding and robotics, what implications may arise from each teacher's evaluation of the teaching practice?

\subsubsection{Localization of the Data Sources}

Instruments of a qualitative nature were used: the semistructured interview and direct observation of teaching practice in the classroom.

Semistructured interview: a qualitative research technique with which oral information may be collected on a concrete theme. The questions are previously defined, but their order and arrangement can vary according to the criteria or convenience of the researcher, looking in depth at certain ideas that are relevant or asking more questions on the subject [83]. Interviews of a duration of between approximately 20-30 minutes each with the two teachers selected on an individual basis were completed at their teaching center. Each teacher was interviewed twice using the same questions. The first time before receiving the training, in order to inquire into their beliefs and perceptions with respect to the STEM approach to educational coding and robotics. The second, subsequent to the training and the classroom practice, in order to ascertain the changes produced during this process and to detect any differences with the initial interview. The interviews were recorded with a mobile phone and transcribed into text [84] for their analysis, with the signed consent of the interviewees. Teachers were informed of the objectives of studying their participation 
as informants in the BotSTEM project, of the open nature of the interview, of their right to not answer questions that might bother them, and, if they changed their opinion, their right of withdrawal in complete anonymity was assured. A general pseudonym (Teacher 1 and Teacher 2) was used to protect the private information of the participants.

The interview questions were organized into three blocks: the first block referred to conceptual and methodological aspects; the second to the attitudes/interests/motivation of the teachers toward the teacher training and the topics that were covered; and third, the beliefs with respect to the difficulties and the specific practice in the classroom.

Observation: a systemic research instrument, which is designed to gather valid and reliable information $[85,86]$ so that real situations may be described through the perceptions of the researcher [87]. With observations, one or various cases may be studied at the same time, describing aspects that other instruments might not appreciate, such as nonverbal expressions, interactions with participants, and even measuring the time employed on each activity $[88,89]$.

An observation template was used to write down the observations within the classroom. This tool places the focus on observing the practice of the teachers when using the STEM approach. The recording of the observation was done in the classroom and with the pupils of one of the teachers giving the science classes who had participated in the interviews as an informant. Observations were taken over three weeks, with two sessions per week, each of which was of a variable duration in accordance with the investigation and the experiments that the teacher presented. The modality of direct-participant observation was used (the investigator was present in the classroom where the observation took place), but the investigator neither developed nor intervened in the sessions. Different devices (video and audio) were also used in the classroom as a means of recording events and field notes were taken that supplemented the information from the template to record aspects that might otherwise have gone unnoticed, in order to subsequently describe the teaching practice in a more detailed way and to compare the data collected during the observation.

The observation template in use consisted of the aforementioned parameters and blocks for the interview, including a matrix of interactions between teacher and pupils based on the model proposed by Flanders [90]. The idea was to analyze the verbal interactions that were taking place in the classroom as the sessions were taking place. The matrix was composed of ten categories (the same categories in both rows and columns). The first six corresponded to the teacher and the last four to the pupil. During the observation, notes were taken every 5-7 seconds, numbering the pairs of verbal interaction. Group work was not included, which was detailed in other sections of the template. It was estimated that a total of six hours of active classroom observation took place.

\subsubsection{Analysis and Interpretation}

It is necessary to employ representations of the contents that were learned by the teachers to analyze the information from the interviews and observations, the language of which was then processed, in order to establish some acceptable correspondences between the results and to propose generalizations that can be applied to other cases. These generalizations can either be applied to other cases as valid propositions for all similar cases (propositional generalizations) or of a more personal kind where the reader involved in the case study can extract personal conclusions (natural generalizations). In this study, the data analysis on the basis of both the observations and the interviews was designed to examine the concepts and the methodologies of the teachers, their perceptions and interests, the difficulties and the practicality of the STEM approach and educational coding and robotics.

Following the transcription of the interviews, they were read on various occasions to identify the categories and the topics worthy of analysis. A more detailed in-depth reading to detect repeated elements was also conducted. To do so, the content was processed through its segmentation into simpler elements, which were more significative and relevant for the investigation [91]. An ad hoc categorization process was followed: categories were 
defined from the information that had been collected on the basis of the information that the participants had shared. The treatment was clarified through consensual agreement over the criteria among the investigators. Taking the above points as a reference and bearing in mind that the interviews provided textual content, the data analysis was done following thematic criteria (taking into consideration the topic that was covered to select segments of text that presented that same topic or similar content and placing them in the same block for analysis) and grammatical criteria (where the sentences of each paragraph were divided into basic units of text, each with their own meaning, having been provided with the transcription of the interview). Finally, the categories and subcategories were combined into an organizational scheme (Box 1), and a theory was formulated that revolved around the responses to the conceptual and the methodological changes, as well as attitudes, interests, motivations, practicalities, and difficulties in connection with STEM teaching.

The recommendations indicated by Flanders were followed for the analysis of the observational data, in keeping with the percentages method, recording the time dedicated to each of the categories, in order to picture and to describe the classroom practice in the most approximate way possible and to observe the interactions between pupils and teacher. The interpretations of the observations noted in the observation manual were added to the analysis to complete and to fine-tune the description of the reality of the classroom experience. Likewise, an attempt was made to differentiate the information that had been gathered from the information that the researchers had provided, seeking in that way to guarantee the rigorous ethical criteria characteristic of qualitative investigation [92].

Box 1. Category analysis.

A. CONCEPTUAL AND METHODOLOGICAL CHANGES: shows the concepts and methods before the teacher-training process and the concepts and methods described after the training process and the classroom practice of the teachers, determining whether there were changes related to the concepts and the methods that they used.

A.1. Concept of science: science-related ideas of the teachers in a generalized way and their new outlook following the teacher training. A.2. Own scientific training: permanent training received and changes and shortcomings arising from the teacher training and the classroom practice.

A.3. Educational innovation in sciences: importance of innovation within the classroom.

A.4. Resources and methodologies: valuation of resources and methodologies employed before and after the teacher training.

A.5. STEM Concept: prior knowledge of the teachers with respect to the approach and changes following the teacher training.

A.6. Concept of educational coding and robotics: previous knowledge of teachers with regard to educational coding and robotics and changes following the teacher training.

A.7. Concept of inquiry: previous knowledge of teachers with regard to this methodology belonging to scientific method and the changes arising after the teacher training.

A.8. Concept of engineering design: previous knowledge of teachers with regard to this methodology and changes arising after the teacher training.

B. ATTITUDES, INTERESTS, AND MOTIVATIONS: shows the beliefs prior to the training and the practice with regard to attitudes, interests, and motivation of the teachers and the children from the point of view of the teacher and the views on those aspects after their implementation.

B.1. Motivation of teachers: personal interest of teachers after training.

B.2. Attitudes of teachers: real, positive, and negative attitudes of the teachers.

B.3. Attitudes of pupils: positive and negative attitudes through the perspectives of the teachers.

C. PRACTICALITIES AND DIFFICULTIES: covers the difficulties, aspects referring to teaching practice and both the benefits and the prejudices indicated by the teachers, based on their initial beliefs and after the implementation of the sessions.

C.1. Resources: determinants relating to materials and resources for implementation in the classroom.

C.2. Timing: determinants relating to the timing of the proposed activities.

C.3. Organization: determinants relating to personal and organizational resources (ratio of pupils, group work, previous experience of the teacher).

C.4. Practice: beliefs and opinions of the teachers regarding the STEM training.

C.5. Benefits: need to implement the approach and their methodologies in the curriculum.

C.6. Prejudices: shortcomings of the approach under study and its implementation and methods. 


\section{Results}

\subsection{Results of the Interviews}

Valuable information on the teachers' visions and attitudes regarding the STEM approach to educational coding and robotics was found after the exhaustive analysis of the interviews and the preparation of their content and their grouping into categories and subcategories.

\subsubsection{Conceptual and Methodological Changes}

The results indicated that the participating teachers had initially begun with certain basic notions of science. So much so that science was defined by naming knowledge areas (mathematics, physics, and chemistry) and was even personified through famous people in scientific areas that the science teachers could recall from their own education as pupils, although it omitted mention of anything in relation to how science was done or other epistemological aspects. This fact may be explained because they reported that their training was based on academic processes such as the Bachillerato (pre-university studies) or in the case of teacher 1, a science-related university course: "[ . . ] At a theoretical level, I do have a good level of knowledge, given that I have followed a university course in sciences", (Teacher 1).

After the training process and the classroom practice, the teachers showed that their concepts of science had at the very least become more problem focused. They defined it as a complex area that was difficult to understand, due to the lack of practical experience based on the surroundings and daily life events: "[ ... ] It's one of the most complex branches of knowledge, and it's very difficult for children to understand", (Teacher 2). Intimately linked to this problem-focused approach toward the concept of science is the need for a change in teacher training. It is considered fundamental for professional development and a change at the core, defining the possibility of teaching sciences in a different way than they had previously done. Likewise, teacher 2 recognized a previous training-related shortcoming and a less than effective resolution in the face of the problems that had arisen in the performance of this sort of focus: "As a teacher perhaps when not having some previous knowledge of science, well... yes, it can be complicated, for example, well I don't know, knowing where to look for material [ ... ]", (Teacher 2).

An important initial difference was detected between the teachers, in relation to the specific concepts of the STEM approach, educational coding and robotics. For instance, teacher 1 affirmed that having a science degree demonstrated greater knowledge that helped to give more accurate descriptions: STEM as an approach that covers various disciplines, in order to approach scientific problems, i.e., educational coding and robotics, as a series of steps or instructions (algorithms), so that the robot can perform a specific activity. The same happened when speaking of the methodologies, briefly explaining the steps to follow to perform an inquiry and the objective of engineering design to resolve problems through the design of prototypes: "The inquiry was the one that raised a hypothesis and based on that hypothesis we searched for possible experiments [... ], to confirm whether our hypothesis might be true or false. Only then did we draw the conclusions.", (Teacher 1). "Engineering design was when..., you designed a contraption, something to solve a problem that you'd set yourself", (Teacher 1).

On the contrary, the other teacher (2) affirmed having no knowledge of the approach, drawing from intuition and personal experiences as a pupil, in order to interpret STEM as a project-based approach and its methodologies as a pathway to move from previous ideas to a series of results or a construction of elements. When asked about educational coding and robotics, the teacher spoke about previous personal experience with pupils, declaring the great capability and facility they had for learning with regard to technology: "[ ... ], They already know perfectly how to handle their bee, [ . . . ], now I have given them the tablet, I have not had to teach them anything [ ... ]", (Teacher 2).

In the second interview, after the teacher training and its application in practice, the responses of both teachers showed greater similarities. They were able to define STEM 
as an approach that helped to resolve problems through different points of view or areas. The inquiry-based method was seen as a process for problem resolution through a series of experiences, which in a practical way helped with problem solving and that, in turn, could develop the critical knowledge of the pupils. Engineering design was understood as the construction of a series of instruments or tools, mentioning in this case that it has as an objective the facilitation of a task in relation to the proposed line of inquiry: "Inquiry methodology [ ... ], you describe a hypothesis, you pose a problem and through different steps and different methodologies the children have to reach a solution [ ... ]", (Teacher 2). With the definition of educational coding and robotics, it was teacher 2 who gave the response that teacher 1 had given in the earlier interview, while teacher 1 pointed to certain difficulties over knowing how the robot could be applied and presented as an instrument for evaluation: "[ ... ] As an instrument for evaluation, because something in which the robot could be incorporated to perform what is properly speaking an experiment never occurred to me for this topic and at this level", (Teacher 1).

When talking of educational innovation in sciences, they agreed on categorizing it as an important part for the interdisciplinary process in which significative learning is acquired that is equally relevant after the experience. In this case, the teachers added that developing this sort of innovation leads to a true change within the classroom, and it increases educational quality, as it awakens the curiosity of pupils and independent knowledge acquisition on the basis of training and the association of ideas and theories on the basis of their experiences: "They build their scientific knowledge and their scientific ideas based on their experiences, and they see it as something with which they can experiment, and they can make mistakes, draw their conclusions, confirm their hypotheses or reject them and return to devise a new line of thought, if their conclusions were not as they had predicted [ ... ], children can also build their own little scientific theories", (Teacher 1).

With regard to both the resources and the methodologies, the teachers in the first interview reported having principally used traditional methods and the textbook. Despite this evidence, teacher 2 sought alternatives to achieve greater dynamism in the classroom and expressed concern over incentivizing the pupils through the use of varied and creative resources: "[ ... ] Abacuses, sticks, rods that to my mind give goods results and everything that occurred to me [ ... ]. And then, for methodology, we clapped our hands and whistled; good activities so that it is not so boring, and we look at each other", (Teacher 2).

After the second interview, the teachers commented that resources were given to them to teach sciences in different ways, although those resources were not employed in most cases, and they limited themselves to the textbook and traditional approaches. Despite these statements, the teachers accepted a great change between the achievements with the book and the sessions that were proposed using the BotSTEM project approach. They became aware that this approach developed greater knowledge because of its practical foundations. Teacher 1 even categorized the textbook view of the earlier topic as ridiculous when compared with the practice in accordance with the STEM approach: "[ ... ] We looked at the topic of forces and seeing it in the book caused quite a laugh, as if you say how ridiculous this is after what had come earlier, so there is an abrupt change between the textbook and the activities", (Teacher 1).

\subsubsection{Attitudes, Interests, and Motivation}

In the first interview, change motivated the teachers, because they considered the STEM approach as something new, capable of bringing change to education, opening the doors to interdisciplinarity: "We need to give a turn to education as it is right now. And any approach that opens the doors to put books aside a bit [ ... ], I think it's great; to me any approach that integrates a bit of everything in a more interdisciplinary and more global way seems to me to be positive", (Teacher 1). That was the reason why they adopted positive open attitudes in general and showed interest, although they also experienced a certain concern, because of their inexperience with these sorts of methodological proposals and because of their confusion of how to implement robotics in a meaningful way: " $[\ldots]$ 
You think, what on earth am I doing [ ... ] it means extra work and a revolution and leaving your comfort zone", (Teacher 2).

With regard to the attitudes of the pupils, the teachers believed that they would be filled with enthusiasm, but that confusion over not being accustomed to these working habits might also play a fundamental role, inciting loss of concentration, insecurity, and a multitude of questions.

In the second interview, they repeated many of the attitudes expressed in the earlier interview. In this case, the motivation of the teachers was centered on the pupils themselves, declaring that the pupils were the ones who had helped them to continue, thanks to their participation, concentration, interest, teamwork, and the knowledge that they demonstrated they had learned. The teachers therefore continued with an open mind, because of the pupils' willingness to learn, in spite of continually expressing their concern over the complexity, the discipline and workload due to such numerous classes: "Let's see, I know that it is much better, the children show a deeper willingness to learn, they are more motivated, they like to experiment, but ouff..., it is still so complex, so Utopian to think that one teacher alone can do this with 27 pupils", (Teacher 1).

As regards the attitudes of the pupils, the teachers noted the same attitudes as they had proposed in the first interview: interest and confusion.

\subsubsection{Teaching Practice and Difficulties}

In the first interview, the difficulties expressed over resources were directed at the textbooks, while these difficulties after the teaching practice turned to the proper use of tools and instruments that the pupils have to employ in their classroom experiences, even mentioning inexperience and the young age of the pupils to assess the utility of these tools and to represent the results in an efficient way: "Use some measurement objects, [ ... ]; Those are tools for older children, that have not been worked with, and when they have to measure they do not know how to do it or how to represent it", (Teacher 2).

Assessing the subcategory of time, in both interviews, the teachers stated that dedication was an important difficulty, affirming that this type of approach entailed a lot of previous preparation and effort and therefore investing a lot of working time that was not usually available to them: "It requires more time, more effort, more involvement (Teacher 1). You must invest a lot of time to prepare the sessions", (Teacher 2).

These difficulties were linked with those of an organizational nature, constituted by the high class ratios that resulted in a great diversity of pupils, onerous teamwork, insufficient work routines, and a lack of space for proper implementation of this type of practice. Other difficulties were highlighted within the teamwork, referring to the relations that existed between the pupils and the individualism at these ages and the lack of experience and the confidence of teachers when implementing these approaches: "I think it's more about their personal way of working, their impulsiveness, that they are not used to team work (Teacher 1). For me the first difficulty was to say what to do, $[\ldots]$, what can we do [ ... ]?", (Teacher 2).

When analyzing the teaching practice, the initial optimism stood out that the teachers had demonstrated when implementing changes to their classroom methods, as well as the solid final satisfaction with the results that they had obtained. The teachers were surprised by the acquisition of knowledge relating to daily life and the acquisition of skills relating to group work. They concluded that they were going to repeat the experience. They were so motivated in view of its impact and the responses of their pupils: "[ ... ] The acquisition of knowledge has been impressive, they have been able to bring the knowledge they have seen into daily life and to see why things happen because of one reason or another, the truth is that they have positively surprised me", (Teacher 2).

With respect to the benefits that the teachers detected in relation to this approach, its interdisciplinary nature may be highlighted, training the pupils in various disciplines at the same time as fostering the habits of teamwork; the acquisition of critical, significant, and independent learning; the perception of science as something close at hand through 
problems of daily life and the construction of knowledge through the capability to select the most relevant information: "STEM methodology favors the acquisition of the same concept from several approaches, that is, it allows the child to select the information to solve a problem", (Teacher 2). The benefits for the teachers were the acquisition of a sense of security and confidence in the face of new challenges and methodological alternatives together with personal and professional satisfaction: " [ . . ], little by little, you see that you are gaining a little more confidence in the process and in the way to carry it out", (Teacher 1$)$. It is worth highlighting that the teachers had problems pointing out their own prejudices, asserting at various points that they did not believe they had any negativity and that they would only describe them as "difficulties". Despite this positive valuation, they highlighted as a negative point that it was a slow process that required a previous foundation that entails time, dedication, and a series of specific materials, on some occasions unavailable to them, which meant it was easy to leave them aside: " $[\ldots]$ it is not an immediate process, [... ]; it requires laying a foundation on which to build learning, which is why it often takes time that unfortunately we do not have", (Teacher 2). The opinion of the families may be added to this prejudice, as it was difficult to work with aspects that were not written down on paper and that the families had no understanding of the teaching-learning process that was carried out: " $[\ldots]$, the parents do not understand how you have worked that because it is not reflected in a palpable way", (Teacher 1).

\subsection{Results of the Observation}

The observations that were noted showed the profile of the class in the context of the integrated STEM proposal, with the aim of describing the interaction between the teacher and the pupils. It likewise showed the categories around which this study revolves in accordance with what was observed in the classroom throughout the sessions that complemented the interviews.

According to the analysis of the data obtained with the class observation template, it was evident that the teacher directed the classes at first with greater spoken interaction. This tendency was compensated as the process advanced with less interaction, although the percentages were still quite high. Rather than pointing to poor implementation of either the process or the STEM approach, it was a veiled observation that neither the teachers nor the pupils had ever worked in this way before. The teacher must therefore guide the pupils through parameters and instructions, so that they can work together in groups. In the same way, in this sense of a guided approach, the high percentage of questions that the teacher asked the pupils may be noted, which was the justification for a more indirect discourse from the teacher that was reassuring for the pupils at the same time as it incentivized their participation.

We may highlight some interesting aspects on classroom teaching practice and the development of the sessions. It was seen how the development of the classes was mainly based on three areas referring to STEM, science, technology, and mathematics, as opposed to the use of engineering that was not in this case employed in any of the classes and was left outside of classroom practice. It is worth noting that the engineering approach was, in fact, the least prominent in the training of the teachers and on which they had no previous experience, not even as students. These areas were principally approached through observational and experimental techniques and through interactive experiential and inquiry-based processes. In this way the participation of the pupils was stimulated through simultaneous dialogue and group work and learning based on daily-life experiences. All those aspects were put into practice in a general way through activities that restructured their ideas, in which the pupils sought to develop activities and to note down the experimental results, modifying previously acquired erroneous knowledge.

With regard to the classroom sessions, some strong points were observed, but also aspects where improvements were necessary, among which experimentation in the classroom, which may be due to a lack of both experience and confidence in experimental work among the teachers. In the same way, it may be pointed out that the STEM approach as 
such was lost in the session referring to the conclusions after the teaching practice. The teachers turned back to traditional evaluation methods, focused on asking pupils questions with the aim of knowing what contents they had learned. This approach was prejudicial at certain times, because it was done so rapidly without leaving sufficient time for the pupils to reassume a leading role, explaining or discussing their own personal experiences and the skills that they had acquired.

\section{Discussion and Conclusions}

In this investigation, the perspectives of the teachers have been examined in relation to the integrated STEM approach to educational coding and robotics, with regard to their own teacher training and educational practice within the classroom. Accordingly, this section offers some reflections and a series of conclusions relating to the study that was undertaken.

As a general overview of the investigation, it may be determined in the same way as Abell [46], that the implementation of educational innovations in primary education in the field of science teaching implies a challenge for teachers. Both initial and permanent teacher training is essential for its success, in order to stimulate learning that leads to scientific literacy on the basis of situations demanded by present-day society, and the achievement of conceptual and methodological changes in relation to the sciences. In this work, the problems arising from the teachers' lack of (content and methodological) knowledge have been explored, as Forbes and Davis and Lucero, Valcke and Shellens [61,64] among others have previously noted. Although not studied in depth, it has also been possible to observe simplistic epistemological viewpoints among the teachers on science and its teaching.

After the study of the teaching-training action that had been developed with a strong practical component, it may be concluded that the integrated STEM approach to educational coding and robotics acceptably promoted educational innovation centered on the science teaching-learning process. This approach promoted positive attitudes and interests among the pupils and the teachers, benefitting working habits, the teacher's knowledge of the pupils and their necessities, cooperative work and both significative and critical learning, and provoking high levels both of satisfaction among the professional teaching staff and of learning among their pupils.

Despite these favorable results, difficulties also arose, such as those described on the one hand in the interviews with the teachers, similar to those in study of Anderson [67] on lack of time and family-related obstacles; and on the other hand, the work of Badia and García [68] on organizational difficulties and the dedication that these approaches require, and even the negative points of their application, as they are slow processes, as Cañal [11] previously affirmed. However, in disaccord with the last-mentioned author and in agreement with what was noted by Toma and Greca [21], the time taken up by the classroom sessions was not much more than those in which a traditional methodology was used, taking into account that they were extended, due to the inexperience of both the teachers and the pupils and because the approach is new to them. This situation may be solved as the pupils acquire working routines and as the teachers gain greater confidence and experience. Other difficulties that were detected are, for example, those referring to the creation of graphic representations, the use of instruments at early ages, and control over behavior, which may be solved through the creation of cooperative working routines at the outset, as one of the teachers indicated in the interviews. Despite that, the weak points arising from the experimentation, and the poor discussion of the results were fundamentally due to lack of experience among the teachers.

It is also thought important to highlight the incongruencies found during the investigation process. For example, the belief of the teachers that an educational change is essential towards the teaching-learning processes that may be based on daily life experiences and practices. However, a contradiction is detected when they are asked about their own classroom praxis, consisting of memorization activities where the pupils are the recipients of a series of theoretical concepts taken from the textbook that plays a leading role alongside the teachers. 
During the study, some limitations were found. First, the contribution of more teachers, due to the low participation of teachers in the pilot phase of the BotSTEM project. Although other teachers introduced practical activities with a STEM approach, the criteria previously established by the researchers prevented them from being selected for the case study. Something that, if addressed in future studies, could broaden the population range. Second, there is no analysis in the current study of science teaching and its influence on students with specific educational needs. Future research could assess how the STEM approach to programming and educational robotics influence the educational practice of teachers in relation to these students, while considering the interaction between teachers and students. The findings may therefore not be sufficient to be generalized for students with educational needs. Third, the scarcity of research regarding the training of primary education teachers in this type of approach prevented any comparison of results from the literature. This type of study from the perspective of the teachers is mostly focused on higher levels or on the students themselves. Furthermore, although this study was based on interviews, it deals with the subjective opinions of the participating teachers speaking from personal experience.

Author Contributions: Conceptualization, C.G.-C. and I.M.G.; Investigation, C.G.-C.; Methodology, M.F.-H.; Project administration, I.M.G.; Supervision, I.M.G.; Writing-original draft, M.F.-H. All authors have read and agreed to the published version of the manuscript.

Funding: This research was funded by the European Union and the SEPIE (Spanish National Agency) under the ERASMUS+ KA2 Strategic Partnerships for School Education European program. Project $\mathrm{n}^{\mathrm{o}}$ 2017-1-ES01-KA201-038204, BotSTEM. Robotics and STEM education for children and primary schools.

Institutional Review Board Statement: The study has a favorable report from the Bioethics Commission of the Universidad de Burgos (Spain).

Informed Consent Statement: Informed consent was obtained from all subjects involved in the study. In addition, the confidentiality of the participants was guaranteed through the use of a pseudonym.

Data Availability Statement: The study meets the ethical and rigorous criteria of qualitative research (informed consent, anonymity of transcripts, feedback). The data presented in this study are available on request from the corresponding author. The data are not publicly available due to privacy reasons.

Acknowledgments: The authors want to thank the teachers for their dedicated collaboration in this project, sharing their knowledge and experiences.

Conflicts of Interest: The authors declare no conflict of interest.

\section{References}

1. Osborne, J.F.; Simons, S.; Collins, S. Attitudes toward Science: A review of the literature and its implications. Int. J. Sci. Educ. 2003, 25, 1049-1079. [CrossRef]

2. Fernandes, I.M.; Pires, D.; Delgado-Iglesias, J. Integraçao de conteúdos CTSA no currículo e nos manuais escolares portugueses de ciencias do $2^{\circ} \mathrm{CEB}$ : Que relaçao de continuidade/discontinuidade? Indagatio Didact. 2016, 8, 986-999. [CrossRef]

3. García-Carmona, A.; Criado, A.M.; Cañal, P. ¿Qué educación científica se promueve para la etapa de primaria en España? Un análisis de las prescripciones oficiales de la LOE. Ensen. Cienc. 2014, 32, 139-157. [CrossRef]

4. Vázquez, A.; Manassero, M.A. Los contenidos de ciencia, tecnología y sociedad en los nuevos currículos básicos de la educación secundaria en España. Indagatio Didact. 2016, 8, 1017-1032. [CrossRef]

5. Rocard, M.; Csermely, P.; Jorde, D.; Lenzen, D.; Walberg, H.; Hemmo, V. Science Education Now: A Renewed Pedagogy for the Future of Europe; Directorate General for Research, Science, Economy and Society: Brussels, Belgium, 2007.

6. Sanmartí, N.; Burgos, B.; Nuño, T. ¿Por qué el alumnado tiene dificultad para utilizar sus conocimientos científicos escolares en situaciones cotidianas? Alambique-Didact. Cienc. Exp. 2011, 67, 62-69.

7. OCDE-Organización para la Cooperación y el Desarrollo Económico. PISA 2006. Marco de la Evaluación. Conocimientos y Habilidades en Ciencias, Matemáticas y Lectura; Santillana: Madrid, Spain, 2006.

8. Gil, D. Psicología Educativa y Didáctica de las Ciencias: Los procesos de enseñanza/aprendizaje de las ciencias como lugar de encuentro. Infanc. Aprendiz. 1993, 16, 171-186. [CrossRef]

9. NAS-National Academy of Science. National Science Education Standards; National Academy Press: Washington, DC, USA, 1995. 
10. Abd-El-Khalick, F.; Waters, M.; Phong-Le, A. Representation of nature of science in high school chemistry textbooks over the past four decades. J. Res. Sci. Teach. 2008, 45, 835-855. [CrossRef]

11. Cañal, P. La investigación escolar, hoy. Alambique-Didact. Cienc. Exp. 2007, 52, 9-19.

12. Gallagher, J.J. Prospective and practicing secondary school science teacher beliefs about the philosophy of science. Sci. Educ. 1991, 75, 121-133. [CrossRef]

13. Niaz, M.; Mazza, A. Nature of Science in General Chemistry Textbooks; Springer: Dordrecht, The Netherlands, 2011.

14. Brooks, G.F.; Brooks, G.M. In Search of Understanding: The Case for Constructivism Classroom; ASCD-Association for Supervision and Curriculum Development: Alexandria, VA, USA, 1993.

15. Martínez-Chico, M. Formación Inicial de los Maestros Para la Enseñanza de las Ciencias. Diseño, Implementación y Evaluación de una Propuesta de Enseñanza. Ph.D. Thesis, University of Almería, Almería, Spain, 2013.

16. Cañal, P.; Criado, A.M.; García, A.; Muñoz, G. La enseñanza relativa al medio en las aulas españolas de Educación Infantil y Primaria: Concepciones didácticas y práctica docente. Investig. Esc. 2013, 81, 21-42. [CrossRef]

17. Tyson, H.; Woodward, A. Why students aren't learning very much from textbooks. Educ. Leadersh. 1989, 47, 14-17.

18. Cuevas, P.; Lee, O.; Hart, J.; Deakort, R. Improving science inquiry with elementary students of diverse backgrounds. J. Res. Sci. Teach. 2005, 42, 337-357. [CrossRef]

19. Burrows, A.; Slater, T. A proposed integrated STEM framework for contemporary teacher preparation. Teach. Educ. Pract. 2015, 28, 318-330.

20. Heil, D.; Pearson, G.; Burger, S. Understanding Integrated STEM Education. Report on a National Study. In Proceedings of the 120th ASEE Annual Conference \& Exposition, Atlanta, GA, USA, 23-26 June 2013. Available online: https: / / www.asee.org/ public/conferences/20/papers/7712/download (accessed on 8 January 2021).

21. Toma, R.B.; Greca, I.M.; Meneses-Villagrá, J.A. Dificultades de maestros en formación inicial para diseñar unidades didácticas usando la metodología de indagación. Rev. Eureka Sobre Ensen. Divulg. Cienc. 2017, 14, 442-457. [CrossRef]

22. Guzey, S.S.; Tank, K.M.; Eang, H.H.; Roehrig, G.; Moore, T.J. A high-quality professional development for teachers of grades 3-6 for implementing engineering into classrooms. Sch. Sci. Math. 2014, 114, 139-149. [CrossRef]

23. Brophy, S.; Klein, S.; Portsmore, M.; Rodgers, C. Advancing Engineering Education in P-12 Classrooms. J. Eng. Educ. 2008, 97, 369-387. [CrossRef]

24. Fan, S.C.; Ritz, J.M. International View of STEM education. In Proceedings of the Pupils' Attitudes towards Technology (PATT-28) Conference: Research into Technological and Engineering Literacy Core Connections, Orlando, FL, USA, 27-28 March 2014; de Vries, M.J., Ed.; cahnged. 2014. Available online: https:/ / www.iteea.org/39488.aspx (accessed on 8 January 2021).

25. Marginson, S.; Tyler, R.; Freeman, B.; Roberts, K. STEM: Country Comparisons: International Comparisons of Science, Technology, Engineering and Mathematics (STEM) Education; Project 2. Final Report; Australian Council of Learned Academies-ACOLA: Melbourne, Australia, 2013.

26. Martin-Hansen, L. Examining ways to meaningfully support students in STEM. Int. J. STEM Educ. 2018, 5, 53-63. [CrossRef] [PubMed]

27. Martín-Páez, T.; Aguilera, D.; Perales-Palacios, F.J.; Vílchez-González, J.M. What are we talking about when we talk about STEM education? A review of literature. Sci. Educ. 2019, 103, 799-822. [CrossRef]

28. Chu, H.-E.; Martin, S.N.; Park, J. A theoretical framework for developing an intercultural STEAM program for Australian and Korean students to enhance science teaching and learning. Int. J. Sci. Math. Educ. 2019, 17, 1251-1266. [CrossRef]

29. Ortiz-Revilla, J.; Adúriz-Bravo, A.; Greca, I.M. A Framework for Epistemological Discussion around an Integrated STEM Education. Sci. Educ. 2020, 29, 857-880. [CrossRef]

30. EC-European Commission. Science Education for Responsible Citizenship; European Commission: Brussels, Belgium, 2015.

31. Honey, M.; Pearson, G.; Schweingruber, H. STEM Integration in K-12 Education: Status, Prospects, and an Agenda for Research; The National Academies Press: Washington DC, USA, 2014.

32. Bybee, R.W. The Case for STEM Education: Challenges and Opportunities; NSTA-National Science Teachers Association Press: Arlington, VA, USA, 2013.

33. NRC-National Research Council. Successful K-12 STEM Education. Identifying Effective Approaches in Science, Technology, Engineering, and Mathematics; The National Academies Press: Washington, DC, USA, 2012.

34. Chamberlin, S.A.; Pereira, N. Differentiating activities for use in a mathematics setting. In Engineering Instruction for High-Ability Learners in K-8 Classrooms; Dailey, D., Cotabish, A., Eds.; Prufrock Press: Waco, TX, USA, 2017; pp. 44-55.

35. Funk, C.; Parker, K. Women and Men in STEM Often at Odds over Workplace Equity; Pew Research Center: Washington, DC, USA, 2018.

36. MacFarlane, B. Infrastructure of comprehensive STEM programming for advanced learners. In STEM Education for High-Ability Learners Designing and Implementing Programming; MacFarlane, B., Ed.; Prufrock Press: Waco, TX, USA, 2016; pp. 139-160.

37. Cañal, P. La alfabetización científica: ¿necesidad o utopía? Cult. Educ. 2005, 16, 245-257. [CrossRef]

38. Martin-Hansen, L. Defining inquiry. Sci. Teach. 2002, 69, 34-37.

39. Osborne, J.; Dillon, J. Science Education in Europe: Critical Reflection; A Report to the Nuffield Foundation; The Nuffield Foundation: London, UK, 2008.

40. English, L.D.; King, D.T. STEM learning through engineering design: Fourth-grade students' investigations in aerospace. Int. J. STEM Educ. 2015, 2, 14. [CrossRef] 
41. Purzer, S.; Hathaway, G.M.; Adams, R.; Xie, C.; Nourian, S. An exploratory study of informed engineering design behaviors associated with scientific explanations. Int. J. STEM Educ. 2015, 2, 9. [CrossRef]

42. Bers, M.U. Coding as a Playground: Programming and Computational Thinking in the Early Childhood Classroom; Routledge: New York, NY, USA, 2018.

43. Bravo, F.A.; Forero, A. La robótica como un recurso para facilitar el aprendizaje y desarrollo de competencias generales. TESI-Rev. Teor. Educ. Educ. Cult. Soc. Inf. 2012, 13, 120-136. [CrossRef]

44. Eguchi, A. Robotics as a Learning Tool for Educational Transformation. In Proceedings of the 4th International Workshop Teaching Robotics \& Teaching with Robotics \& 5th International Conference Robotics in Education, Padova, Italy, 18 July 2014. Available online: http:/ / www.terecop.eu/index1.htm (accessed on 8 January 2021).

45. Ruiz-Velasco, E.; García, J.V.; Rosas, L.A. Robótica Pedagógica Virtual Para la Inteligencia Colectiva. IX Encuentro Virtual Educa, Zaragoza, Spain. 2008. Available online: http://hdl.handle.net/20.500.12579/1351 (accessed on 8 January 2021).

46. Han, S.; Yalvac, B.; Capraro, M.M.; Capraro, R.M. In-service Teachers' Implementation and Understanding of STEM Project Based Learning. EURASIA J. Math. Sci. Tech. Educ. 2015, 11, 63-76. [CrossRef]

47. Margot, K.C.; Kettler, T. Teachers' perception of STEM integration and education: A systematic literature review. Int. J. STEM Educ. 2019, 6, 2. [CrossRef]

48. Flores, J.; Caballero, M.C.; Moreira, M.A. Ideas epistemológicas sobre la naturaleza de la ciencia de docentes en formación de biología y de química. Rev. Qurriculum 2013, 26, 101-133.

49. Fernández, I.; Gil, D.; Carrascosa, J.; Cachapuz, A.; Praia, J. Visiones deformadas de la ciencia transmitidas por la enseñanza. Ensen. Cienc. 2002, 20, 477-488.

50. Cortés, A.L.; de la Gándara, M.; Calvo, J.M.; Martínez, M.B.; Ibarra, J.; Arlegui, J.; Gil, M.J. Expectativas, necesidades y oportunidades de los maestros en formación ante la enseñanza de las ciencias en la Educación Primaria. Ensen. Cienc. 2012, 30, 155-176. [CrossRef]

51. Korthagen, F.; Loughran, J.; Russel, T. Developing fundamental principles for teacher education programs and practices. Teach. Teach. Educ. 2006, 22, 1020-1041. [CrossRef]

52. Breiner, J.M.; Johnson, C.C.; Harkness, S.S.; Koehler, C.M. What is STEM? A discussion about conceptions of STEM in education and partnerships. Sch. Sci. Math. 2012, 112, 3-11. [CrossRef]

53. Chesky, N.Z.; Wolfmeyer, M.R. Philosophy of STEM Education. A Critical Investigation, 1st ed.; Palgrave Macmillan: New York, NY, USA, 2015.

54. Bruce-Davis, M.N.; Gubbins, E.J.; Gilson, C.M.; Villanueva, M.; Foreman, J.L.; Rubenstein, L.D. STEM high school administrators', teachers', and students' perceptions of curricular and instructional strategies and practices. J. Adv. Acad. 2014, 25, 272-306. [CrossRef]

55. Nadelson, L.S.; Seifert, A. Perceptions, engagement, and practices of teachers seeking professional development in place-based integrated STEM. Teach. Educ. Pract. 2013, 26, 242-265.

56. García-Carrillo, C.H. Perspectivas del Profesorado Sobre la Enseñanza del STEM, Programación y Robótica Educativas en Educación Primaria. Master's Thesis, Universidad de Burgos, Burgos, Spain, 2019.

57. Pujol, R.M. Pensar en la escuela primaria para pensar en la formación de su profesorado, desde la DCE, en el marco del nuevo grado. In Ciencias Para el Mundo Contemporáneo y Formación del Profesorado en Didáctica de las Ciencias Experimentales; Jiménez, M.R., Ed.; Universidad de Almería: Almería, Spain, 2008; pp. 354-361.

58. Greca, I.M. Supporting pre-service elementary teachers in their understanding of inquiry teaching through the construction of a third discursive space. Int. J. Sci. Educ. 2016, 38, 791-813. [CrossRef]

59. Murphy, C.; Neil, P.; Beggs, J. Primary science teacher confidence revisited: Ten years. Educ. Res. 2007, 49, 415-430. [CrossRef]

60. Porlán, R.; Martín, R.; Rivero, A.; Harres, J.; Azcárate, P.; Pizzato, M. El cambio del profesorado de ciencias: Marco teórico y formativo. Ensen. Cien. 2010, 28, 31-46.

61. Lucero, M.; Valcke, M.; Schellens, T. Teachers' beliefs and self-reported use of inquiry in Science Education in Public Primary Schools. Int. J. Sci. Educ. 2013, 35, 1407-1423. [CrossRef]

62. McDonald, S.; Butler-Songer, N. Enacting classroom inquiry: Theorizing teachers' conceptions on science teaching. Sci. Educ. 2008, 27, 45-60. [CrossRef]

63. Aizpun, A. La identidad de las Escuelas de Magisterio. In Conference Address Presented at the Seminario de Segovia Organizado por la Dirección General de Ordenación Educativa y del Profesorado del MEC; Ministerio de Educación y Cultura: Segovia, Spain, 1980.

64. Forbes, C.T.; Davis, E.A. Curriculum design for inquiry. Pre-service elementary teachers' mobilization and adaptation of science curriculum materials. J. Res. Sci. Teach. 2010, 47, 820-839. [CrossRef]

65. Charrier, M.; Cañal, P.; Rodrigo, M. Las concepciones de los estudiantes sobre la fotosíntesis y la respiración: Una revisión sobre la investigación didáctica en el campo de la enseñanza y el aprendizaje de la nutrición de las plantas. Ensen. Cien. 2006, 24, 401-410.

66. Johnson, C.C. Effective professional development and change in practice: Barriers teachers encounter and implications for reform. Sch. Sci. Math. 2006, 106, 150-161. [CrossRef]

67. Anderson, R.D. Study of Curriculum Reform; Government Printing Office: Washington, DC, USA, 1996.

68. Badia, A.; García, C. Incorporación de las TIC en la enseñanza y el aprendizaje basados en la elaboración colaborativa de proyectos. RUSC-Univ. Knowl. Soc. J. 2006, 3, 42-54. [CrossRef] 
69. NSB-National Science Board. Science and Engineering Indicators 2018. NSB-2018-1; National Science Foundation: Alexandria, VA, USA, 2018.

70. OECD-Organisation for Economic Co-Operation and Development. What Are Tertiary Students Choosing to Study; OECD Publishing: Paris, France, 2014.

71. Pretz, K. A Look at the State of Engineering Education Worldwide. In IEEE Spectrum Special Report; 2016; September Issue. Available online: https://web.archive.org/web/20190214013848/http:/ / theinstitute.ieee.org/career-and-education/education/ a-look-at-the-state-of-engineering-education-worldwide (accessed on 8 January 2021).

72. Tai, R.H.; Qi Liu, C.; Maltese, A.V.; Fan, X. Planning early for careers in science. Science 2006, 312, 1143-1145. [CrossRef] [PubMed]

73. Stake, R. Investigación con Estudio de Casos; Morata: Madrid, Spain, 2005.

74. Yin, R.K. Case Study Research: Design and Methods; SAGE Publications: Thousand Oaks, CA, USA, 2003.

75. Simons, H. El Estudio de Caso: Teoría y Práctica; Morata: Madrid, Spain, 2009.

76. León, O.; Montero, I. Métodos de Investigación en Psicología y Educación. Las Tradiciones Cuantitativas y Cualitativas; Mc Graw Hill: Madrid, Spain, 2015.

77. Stake, R. Qualitative Research. Studying How Things Work; The Guildford Press: New York, NY, USA, 2010.

78. Gobierno de España. Ley Orgánica 8/2013, de 9 Diciembre, Para la Mejora de la Calidad Educative; Boletín Oficial del Estado n 295, de 10 de diciembre de 2013; Agencia Estatal Boletín Oficial del Estado: Madrid, Spain, 2013; Referencia: BOE-A-2013-12886.

79. Junta de Castilla y León. Decreto 26/2016, de 21 de Julio, Por el Que se Establece el Currículo y se Regula la Implantación, Evaluación y Desarrollo de la Educación Primaria en la Comunidad de Castilla y León; Boletín Oficial de Castilla y León nº 142, de 25 de julio de 2016; Junta de Castilla y León: Valladolid, Spain, 2016; Referencia: BOCYL-D-25072016-3.

80. Junta de Castilla y León. Acuerdo 29/2017, de 15 de Junio, de la Junta de Castilla y León, Por el Que se Aprueba el II Plan de Atención a la Diversidad en la Educación de Castilla y León 2017-2022; Boletín Oficial de Castilla y León nº 115, de 19 de junio de 2017; Junta de Castilla y León: Valladolid, Spain, 2017; Reference: BOCYL-D-19062017-16.

81. Varas, M.; Zariquiey, F. Técnicas formales e informales de aprendizaje cooperativo. In Alumnos Con Altas Capacidades y Aprendizaje Cooperativo; Torrego, J.C., Ed.; Fundación SM: Madrid, Spain, 2011; pp. 505-560.

82. Parra, J.E.; Castro, C.; Amariles, M. Casos de éxito de la aplicación de la metodología de aprendizaje basado en problemas ABP. IngEam-Rev. Investig. Fac. Ing. EAM 2014, 1, 15-22.

83. McMillan, J.H.; Schumacher, S. Introducción al Diseño de Investigación Cualitativa; Pearson Education: Madrid, Spain, 2011.

84. Becker, H.S. Sociological Work: Method and Substance; Transaction Books: New Brunswick, NJ, USA, 1970.

85. Marshall, C.; Rossman, G.B. Designing Qualitative Research; SAGE Publications: Newbury Park, CA, USA, 1989.

86. Ander-Egg, E. Métodos y Técnicas de Investigación Social; Lumen Hvmanitas: Buenos Aires, Argentina, 2003.

87. Erlandson, D.A.; Harris, E.L.; Skipper, B.; Allen, S.D. Doing Naturalistic Inquiry: A Guide to Methods; SAGE Publications: Newbury Park, CA, USA, 1993.

88. Bunge, M. La Investigación Científica: Su Estrategia y su Filosofía; Siglo XXI: México DF, Mexico, 2007.

89. Schmuck, R. Practical Action Research for Change; IRI/Skylight Training and Publishing: Arlington Heights, IL, USA, 1997.

90. Flanders, N.A. Análisis de la Interacción Didáctica; Anaya: Madrid, Spain, 1977.

91. Rodríguez, G.; Gil, J.; García, E. Metodología de la Investigación Cualitativa, 2nd ed.; Aljibe: Archidona, Spain, 1999.

92. Guba, E.G.; Lincoln, Y.S. Fourth Generation Evaluation; SAGE Publications: Newbury Park, CA, USA, 1989. 